\title{
Proposed use of the international classification of functioning, disability and health to evaluate quality of life after an amputation
}

\author{
Proposta de utilização da classificação internacional \\ de funcionalidade, incapacidade e saúde na avaliação \\ da qualidade de vida de pessoas com amputação
}

\section{Andersom Ricardo Fréz ${ }^{[a]}$, Amirah Ali Abdallah ${ }^{[b]}$, Christiane Riedi ${ }^{[c]}$, Janaine Galindo ${ }^{[\mathrm{d}]}$, João Afonso Ruaro ${ }^{[\mathrm{e}]}$, Simone de Carvalho Ribeiro ${ }^{[\mathrm{f}]}$}

[a] Physiotherapist, Master's Program in Health, Interdisciplinary and Rehabilitation, Universidade Estadual de Campinas (Unicamp), professor at Universidade Estadual do Centro-Oeste (Unicentro), Guarapuava, PR - Brazil, e-mail: andersom_frez@yahoo.com.br

[b] Physioterapist, graduated from Faculdade Anglo-Americano (FAA), Foz do Iguaçu, PR - Brazil, e-mail: amirahabd@hotmail.com

[c] Physiotherapist, Master's Program in Physical Therapy, Universidade Metodista de Piracicaba (Unimep), professor at Universidade Estadual do Centro-Oeste (Unicentro), Guarapuava, PR - Brazil, e-mail: christiane_riedi@hotmail.com

[d] Physioterapist, graduated from Faculdade Anglo-Americano (FAA), Foz do Iguaçu, PR - Brazil, e-mail: janegalindo-@hotmail.com

[e] Physioterapist, Post Graduate Program in Health Sciences at Universidade Federal do Rio Grande do Norte (UFRN), professor at Universidade Estadual do Centro-Oeste (Unicentro), Guarapuava, PR - Brazil, e-mail: joaoruaro@gmail.com

[f] Physioterapist, graduated from Faculdade Anglo-Americano (FAA), Foz do Iguaçu, PR - Brazil, e-mail: sihmoninha@hotmail.com

\section{Abstract}

Objective: To quantify the quality of life of people with a lower limb amputation, and to propose a relationship between the quality of life and the International Classification of Functioning, Disability and Health (ICF). Materials and methods: After a retrospective study of medical records, 15 amputees met the inclusion criteria. The characteristics of the amputation and quality of life were evaluated, and both were correlated with the ICF. The 36-Item Short-Form Survey (SF-36) was used to assess quality of life. Results: It was possible to establish ICF codes for levels of amputation and the quality of life. A high and significant correlation was found between quantitative descriptors of the ICF and SF-36 scores $(r=-0.9376, p<0.0001)$. 
Conclusion: People with a lower limb amputation showed a reduced quality of life, which was reflected in scores from a generic questionnaire and their correlation with the ICF.

Keywords: Amputation. Evaluation. Quality of life. International Classification of functioning, disability and health.

Resumo

Objetivo: Quantificar a qualidade de vida de sujeitos com amputação de membros inferiores e propor uma relação entre a qualidade de vida e a Classificação Internacional de Funcionalidade, Incapacidade e Saúde (CIF). Materiais e métodos: Após estudo retrospectivo, por meio de consulta nos cadastros dos usuários, 15 pessoas com amputação enquadraram-se nos critérios de inclusão. Destes foram identificadas as características da amputação, além de avaliar a qualidade de vida por meio do questionário SF-36, correlacionando-as com a CIF. Resultados: Foi possível estabelecer códigos da CIF tanto para os níveis de amputação quanto para a qualidade de vida por meio dos domínios do questionário SF-36. A correlação entre os descritores quantitativos da CIF com os escores do SF-36 foi considerada alta $(r=-0,9376)$ e significante $(p<0,0001)$. Conclusões: A qualidade de vida de sujeitos amputados fica comprometida, fato que pode ser observado tanto na análise de um questionário genérico para avaliação desta variável quanto pela sua correlação com a CIF.

Palavras-chave: Amputação. Avaliação. Qualidade de vida.

Classificação Internacional de funcionalidade, incapacidade e saúde.

\section{Introduction}

Quality of life is one of several variables by which scientific studies seek to examine the lives of individuals in relation to their skills and activity levels (1). Amputations resulting from traumatic injuries stand out among conditions that negatively influence the quality of life $(2,3,4)$. Understanding the impact of disability on the quality of life can be extremely useful in determining the effectiveness of treatment and rehabilitation protocols. Changes in quality of life can be used as an outcome measure of the rehabilitation process (5), which is not simply intended to favor functional improvement, but also to provide a better quality of life (6).

After an amputation, it is important for individuals to undergo an appropriate treatment program, to enable them to perform their activities of daily living (ADLs) with greater functionality and, possibly, achieve a better quality of life (7). Health-related quality of life is one of the most important criteria for rehabilitation because its evaluation facilitates decision-making and adjustments in rehabilitation programs (1). Rehabilitation can be customized according to an individual's needs (i.e., according to factors that negatively influence their quality of life).
A good surgery and subsequent prosthesis use are not sufficient to guarantee that all of an amputee's quality of life-related needs will be met (8). Literature reviews by Silva et al. (9) and Vidal et al. (10) found no consensus on the domains that should be evaluated by research on quality of life for individuals with lower limb amputation. There are no tools to quantify these subjects' experiences systematically, and no consensus on what scales or instruments should be used $(10,11)$. The use of nonvalidated or nonstandardized instruments should be avoided because their use makes it impossible to compare results, jeopardizes the reliability of the research, and hinders reproducibility (12).

The International Classification of Functioning, Disability, and Health (ICF) has sought to standardize the language related to disabilities. The ICF was proposed by the World Health Organization (WHO) to provide a paradigm shift from a biomedical model of rehabilitation and to increase understanding of human functioning. The ICF has become a suitable tool to identify the conditions of functionality, environment, and personal characteristics that affect quality of life. The ICF assists in communication and information exchange, and it allows for different perspectives to be addressed to suit patients' individual needs $(13,14)$. 
The aims of this study were to describe and quantify the quality of life of individuals with lower limb amputation, and to establish a relationship between quality of life and the ICF.

\section{Material and methods}

This research was designed as a cross-sectional study based on a descriptive epidemiological model of subjects with lower limb amputation. The goals were to identify the amputation and quality of life characteristics of these subjects, and to correlate them with the ICF.

To be included in the study, subjects must meet the following criteria: 1) age over 18 years, 2) currently undergoing or previously underwent lower limb amputation, and 3) currently attending, or previously attended the Centro de Reabilitação of the Centro de Especialidades Médicas (CR/CEM) in the city of Foz do Iguaçu, Brazil. Subject eligibility did not depend on their gender, the level or cause of their amputation, or whether they were prosthetized. Subjects who presented difficulties in verbal or written communication, who were clinically diagnosed with any neurological disease, and who did not accept the invitation to participate in the study were excluded. The study was initiated after approval by the Ethics Committee of the Faculdade Assis Gurgacz (ruling number 064/2010). It adhered to Brazilian laws and guidelines concerning research in humans.

Amputees in Foz do Iguaçu are referred to the Prosthetics and Orthotics Department at CR/CEM, where they are registered and, after screening and evaluation, are sent for acquisition of assistive devices according to their needs. In September and October 2010, we began a retrospective study. We consulted the records of individuals who visited the Prosthetics and Orthotics Department from January 2008 through June 2010. We identified 165 entries, of which 90 were subjects with lower limb amputations. The others did not fit the inclusion criteria. We successfully contacted 50 of the 90 amputees; however, only 15 agreed to participate.

The 15 amputees that met the inclusion criteria and agreed to participate received guidance in advance on the major difficulties in rehabilitation, ways to facilitate transfers, decubitus change, demonstrations of orthosis types that aid in locomotion in terms of normal gait, as well as guidance in ADLs.
Subsequently, subjects signed an informed consent form and responded to questionnaires. We guaranteed the confidentiality and anonymity of responses. All questionnaires were correctly completed.

The following variables were assessed in the interview by questioning: age, gender, use of prosthesis, level and cause of amputation, time of amputation, time of prosthesis use, length of physical therapy, complications, level of dependence in ADLs, and lifestyle.

We assessed quality of life by applying the Brazilian version of the 36-Item Short-Form Survey (SF-36), translated and validated by Ciconelli et al. (15). It consists of eight scores, which can be divided into two summary measures: physical and mental health. The first measure includes domains for physical functioning, physical problems, bodily pain, and general health perception. The second measure includes domains for mental health, emotional problems, social functioning, and vitality. All scores range from 0 to 100 .

To avoid any pressure on amputees, they were approached and interviewed by previously trained external evaluators who were not affiliated with the CR/CEM. There was no cost to participants.

Upon completion of the evaluation, two researchers, both of whom were trained in handling the ICF and did not participate in the approach and interview of subjects, independently selected components and categories of the ICF that could be applied to characterize the domains of the questionnaires. Both came to a consensus on the inclusion or exclusion of components and categories. If there was disagreement, a third researcher was to be asked to resolve the differences; however, this step proved unnecessary. To establish the score of quality of life and the components and domains of the SF-36, we considered the median of responses reported.

To correlate the SF-36 with the ICF, the subjects were evaluated according to the proposed variables. For all agreed codes, we proposed a qualifier. Whereas the quantitative descriptors of ICF increase according to the severity of the problem (13), scores of the SF-36 are higher for subjects with better quality of life (15). Because of this inverse relationship, when we assigned qualifiers for the ICF items of the SF-36, we calculated the difference between the maximum score of the SF-36 and the ranges of quantitative descriptors of the ICF.

For data analysis, we used descriptive statistics with mean, standard deviation (SD), and medians. 
The Spearman test was employed to verify the correlation. A p-value $<0.05$ was considered significant. GraphPad Instat software was used.

\section{Results}

Among the 15 subjects, 10 (67\%) were male and 5 (33\%) were female. The mean age was $48.0 \pm 17.6$ years. Amputation was due to trauma in 11 subjects (73\%) and due to vascular dysfunction in 4 subjects (27\%). The average time since amputation was $8.3 \pm$ 8.3 (range 1-30) years. The average time since prosthesis fitting was $5.5 \pm 6.6$ (range $0-20$ ) years; however, 5 subjects were not prosthetized. All subjects had undergone or were currently in physical therapy, for a mean period of $10.4 \pm 14.9$ (range 1-60) months. Of the possible complications after an amputation, phantom pain was cited by $40 \%$, phantom sensation by $33 \%$, and stump pain by $7 \%$. In terms of lifestyle, $40 \%$ reported being smokers, $20 \%$ consumed alcohol, and 93\% were sedentary. We established a relationship between the level of amputation and the ICF categories (Table 1).

The ICF categories were chosen in accordance with the highest level of detail possible to characterize the domains of the SF-36 accurately (Table 2).

As the ICF and SF-36 presented an inverse relationship between qualitative descriptors, we subtracted from the maximum score of the SF-36 median responses, thereby establishing a relationship between the qualifiers of the ICF and the SF-36 (Table 3).

The correlation coefficient between the median of the ICF qualifiers and SF-36 scores was $r=-0.9376$, demonstrating a high inverse correlation ( $p<0.0001)$. Correlations between the SF-36 and the ICF qualifiers, as well as the level of quality of life, are shown in Table 4.

The quality of life was determined for the amputation level (Table 5), according to the median of responses.

Table $\mathbf{1}$ - ICF categories for amputation levels

\begin{tabular}{lrcl}
\hline Amputation level & N (\%) & ICF category & ICF category description \\
\hline Transfemoral & $6(40.0)$ & s7500.327 & Structure of thigh, severe impairment, partial absence, distal \\
Transtibial & $8(53.3)$ & $s 7501.327$ & Structure of leg, severe impairment, partial absence, distal \\
Mid-foot & $1(6.7)$ & $s 7502.327$ & Structure of ankle and foot, severe impairment, partial absence, distal \\
\hline
\end{tabular}

Source: Research data.

Table 2 - Proposed relationship between SF-36 domains and ICF categories

(To be continued)

\begin{tabular}{lcl}
\hline SF-36 domains & ICF category & ICF category description \\
\hline b760 & d2 & $\begin{array}{l}\text { Control of voluntary movement functions: Functions associated with control over and } \\
\text { coordination of voluntary movements. } \\
\text { General tasks and demand: General aspects of carrying out single or multiple tasks, } \\
\text { organizing routines, and handling stress. } \\
\text { Physical functioning }\end{array}$ \\
& d4 & $\begin{array}{l}\text { Mobility: Moving by changing body position or location or by transferring from one } \\
\text { place to another, by carrying, moving, or manipulating objects, by walking, running, } \\
\text { or climbing, and by using various forms of transportation. }\end{array}$ \\
\hline Role-physical & b1644 & $\begin{array}{l}\text { Insight: Mental functions of awareness and understanding of oneself and one's } \\
\text { behavior. }\end{array}$ \\
\hline Bodily pain & b280 & $\begin{array}{l}\text { Sensation of pain: Sensation of unpleasant feeling indicating potential or actual } \\
\text { damage to some body structure. }\end{array}$ \\
\hline General health & b & $\begin{array}{l}\text { Body functions: Physiological functions of the body systems. } \\
\text { Activity: The execution of a task or action by an individual. Participation: Involvement } \\
\text { in a life situation. }\end{array}$ \\
\hline
\end{tabular}


Table 2 - Proposed relationship between SF-36 domains and ICF categories

(Conclusion)

\begin{tabular}{lcl}
\hline SF-36 domains & ICF category & ICF category description \\
\hline Vitality & b1300 & $\begin{array}{l}\text { Energy level: Mental function that produce vigor and stamina. } \\
\text { General physical endurance: Functions related to the general level of tolerance of } \\
\text { physical exercise or stamina. }\end{array}$ \\
\hline Social functioning & b122 & $\begin{array}{l}\text { Global psychosocial functions: General mental functions, as they develop over the } \\
\text { life span, required to understand and constructively integrate the mental functions } \\
\text { that lead to the formation of the interpersonal skills needed to establish reciprocal } \\
\text { social interactions, in terms of both meaning and purpose. } \\
\text { Interpersonal interactions and relationships: Carrying out the actions and tasks } \\
\text { required for basic and complex interactions with people (strangers, friends, relatives, } \\
\text { family members, and lovers) in a contextually and socially appropriate manner. }\end{array}$ \\
\hline Role-emotional & $\mathrm{d} 7$ & $\begin{array}{l}\text { Emotional functions: Specific mental functions related to the feeling and affective } \\
\text { components of the processes of the mind. }\end{array}$ \\
\hline Mental health & b152 & Mental function, unspecified. \\
\hline
\end{tabular}

Source: Research data.

Table 3 - Relationship between quantitative and qualitative descriptors of the ICF and the scores of the SF-36

\begin{tabular}{cccccc}
\hline \multirow{2}{*}{ ICF Qualifier } & \multicolumn{2}{c}{ ICF } & & \multicolumn{2}{c}{ SF-36 } \\
\cline { 2 - 3 } \cline { 5 - 6 } & $\begin{array}{c}\text { Quantitative magnitude of } \\
\text { the level of health }\end{array}$ & $\begin{array}{c}\text { Qualitative magnitude of } \\
\text { the level of health }\end{array}$ & & Score & Qualitative quality of life score \\
\hline .0 & $0-4 \%$ & No problem & & $96-100$ & Highest \\
.1 & $5-24 \%$ & Mild problem & & $76-95$ & Good \\
.2 & $25-49 \%$ & Moderate problem & & $51-75$ & Regular \\
.3 & $50-95 \%$ & Severe problem & & $5-50$ & Poor \\
.4 & $96-100 \%$ & Complete problem & $0-4$ & Lowest \\
\hline
\end{tabular}

Source: Research data.

Table 4 - Median values assigned to SF-36 domains and ICF qualifiers, and the correlation between these variables

\begin{tabular}{lccccr}
\hline SF-36 Domains & SF-36 Score & ICF Qualifier & Qualitative descriptor & $\mathbf{R}$ & p-value \\
\hline Physical functioning & 50.0 & .3 & Poor & -0.9442 & $<0.0001$ \\
Role-physical & 50.0 & .3 & Poor & -0.9990 & $<0.0001$ \\
Bodily pain & 80.0 & .2 & Regular & -0.6861 & 0.047 \\
General health & 72.0 & .2 & Regular & -0.9905 & $<0.0001$ \\
Vitality & 50.0 & .3 & Poor & -0.8444 & $<0.0001$ \\
Social functioning & 87.5 & .1 & Good & -0.9913 & $<0.0001$ \\
Role-emotional & 33.3 & .3 & Poor & -1.0000 & $<0.0001$ \\
Mental health & 56.0 & .2 & Regular & -0.8581 & $<0.0001$ \\
\hline
\end{tabular}

Source: Research data. 
Table 5 - Quality of life according to the level of amputation

\begin{tabular}{lccc}
\hline Amputation level & N (\%) & SF-36 (median) & Qualitative descriptor \\
\hline s7500.327 & $6(40.0)$ & 49 & Poor \\
s7501.327 & $8(53.3)$ & 70 & Regular \\
s7502.327 & $1(6.7)$ & 35 & Poor \\
\hline
\end{tabular}

Source: Research data.

\section{Discussion}

For a successful rehabilitation, it is necessary to have scales or specific questionnaires that are able to quantify the patient after a lower limb amputation, as well as an understanding of the relationships of these scales with the amputee's quality of life and prosthesis use. The lack of studies that deal with quality of life in lower limb amputees underscores the need for this type of study (16).

According to Larsson et al. (17), the quality of life of amputees is likely to be improved by efforts at rehabilitation that are focused on improving mobility; an increase in physical activity and consequent reduction in physical limitations and dependencies can improve the quality of life. However, Amini et al. (1) reported that psychological problems stand out as key influencers of quality of life.

Although the rehabilitation process focuses mainly on physical functioning, a study using a quality of life assessment (18) concluded that the rehabilitation process should include care for issues such as pain, psychosocial issues (e.g., body image), as well as adaptation to amputation and prosthesis use. Through this global approach, it is possible to increase the quality of life of people with lower limb amputation.

In this research, we used the SF-36 to evaluate the physical and mental components of the quality of life. The SF-36 is regarded as a generic tool for assessing quality of life, and it is not specific to subjects with lower limb amputation. However, many studies have used this tool to assess this population $(1,16,19,20)$.

Furthermore, among the generic tools for assessing the quality of life, the SF-36 is the most used worldwide (21), because the use of nonvalidated or nonstandardized instruments should be avoided because their use makes it impossible to compare results, jeopardizes the reliability of the research, and hinders reproducibility (12).
As a result of the lack of uniformity in procedures and evaluation instruments, results from studies with different methodologies cannot be compared or integrated with one another, which lowers the efficiency of rehabilitation processes (22).

The ICF presents a system of terminology for a uniform international classification to describe the problems associated with health conditions and relevant environmental factors, thus providing a common language for professionals involved in rehabilitation $(23,24)$. However, the ICF does not replace other forms of assessment, and both interact. Farin et al. (25) reported that several studies have shown this interaction through use of existing evaluative instruments in order to describe the congruence between the ICF and the measuring instruments used in rehabilitation.

Use of the ICF model to evaluate quality of life has been proposed in other studies. To evaluate limitations in activities and restrictions in social participation of individuals with osteoarthritis, Pollard et al. (26) used the SF-36 questionnaire to establish the relationship between these areas and the ICF, but they did not assign codes for the domains. Associating the proposed creation of the core set to repetitive strain injury and work-related musculoskeletal injury, they reported that some domains of the SF36 may be related to categories of body functions (b1300, b1301, b152, b280), as well as other categories of activities and participation (d230, d430, d445, d450, d520, d540, d640, d850, d855, d910) (27). According to the same authors, tools such as the SF-36, the Health Assessment Questionnaire (HAQ), and the Self-administered Comorbidity Questionnaire (SCQ) have been suggested by the WHO as a standard composition of core sets. In the present study, the proposal was not to create a core set, but to use the ICF model and its respective codes, which were correlated with an already established evaluative tool 
to measure quality of life. This approach was used because the core set for people with amputations is being developed (24).

Other research has also sought to use the ICF as a basis for comparing instruments for measuring variables. For example, Monteiro et al. (28) attempted to validate an instrument (DSF-84) for evaluating the functional and social performances of individuals with lower limb amputation based on the ICF. Their results proved that the DSF-84 is a reliable and valid instrument for this population, findings that may be considered analogous to those of the present study.

Results from studies such as Burger's (29) reinforce the idea that the ICF should be implemented in the everyday clinical practice of professionals working with patients who need prostheses and/or orthosis. The findings of our own study reinforce this idea of using the ICF in clinical practice.

Ultimately, the quality of life is one of the most important factors in the functional recovery process carried out by physiotherapists, including using the ICF to measure progress. The latter use of the ICF was suggested by the results of Kohler et al. (30), who found that the ICF appears to have content validity and sensitivity as a measure of changes in patients after lower limb amputation.

Even with a small sample of subjects with lower limb amputation it was possible to establish a significant correlation between the ICF and another validated tool for the standardization of nomenclature. However, the codes assigned to the ICF classification of amputee subjects and the relationship between the domains of the SF-36 and the ICF should be considered as dynamic, in keeping with one of the features of the ICF: namely, that the proposed classification should not be regarded as exclusive, but rather as a basis for new proposals.

\section{Conclusions}

The ICF can be used as a way of assessing the quality of life of individuals with amputation, as indicated by the strong correlation between the ICF qualifiers and the scores of the SF-36. Both instruments confirm that these individuals have impaired quality of life after amputation.

\section{References}

1. Amini R, Shojaee H, Haghani H, Masoomi M, Davarani HH. Physical injuries and quality of life in blind war survivors: a cross-sectional study. Arch Iran Med. 2010; 13(6): 504-8.

2. Alonso J, Ferrer M, Gandek B, Ware JE Jr, Aaronson NK, Mosconi P, et al. Health-related quality of life associated with chronic conditions in eight countries: results from the International Quality of Life Assessment (IQOLA) Project. Qual Life Res. 2004;13(2):283-98.

3. Klute GK, Berge JS, Orendurff MS, Williams RM, Czerniecki JM. Prosthetic intervention effects on activity of lower-extremity amputees. Arch Phys Med Rehabil. 2006;87(5):712-22.

4. Peters EJG, Childs MR, Wunderlich RP, Harkless LB, Armstrong DG, Lavery LA. Functional status of persons with diabetes-related lower-extremity amputations. Diabetes Care. 2001;24(10):1799-804.

5. Kempen M, Ormel J, Brilman I, Relyveld J. Adaptive responses among Dutch elderly: the impact of eight chronic medical conditions on health-related quality of life. Am J Public Health. 1997;87(1):38-44.

6. Maggi LE, Rocha PVS, Barbosa PMR, Oliveira RA. Prontuário eletrônico para avaliação fisioterapêutica de amputados. Rev Movimenta. 2010;3(1):4-15.

7. Almeida LF, Camargos GV, Corrêa CL. Mudanças reorganizacionais nos córtices somatossensorial e motor em amputados: revisão da literatura. Rev Neurocienc. 2009;17(2):146-55.

8. Poljak-Guberina R, Živković O, Muljačić A, Guberina M, Bernt-Živković T. The amputees and quality of life. Coll Antropol. 2005;29(2):603-9.

9. Silva CAG. Masiero D, Chamlian TR. Qualidade de vida em amputados de membros inferiores. Med Reabil. 2008;27(1):11-4.

10. Vidal ALA, Santos CC, Nishimaru S, Chamlian TR, Masiero D. Avaliação da qualidade de vida em pacientes amputados de membros inferiores. Med Reabil. 2004;23(1): 12-7.

11. Kageyama ERO, Yogi M, Sera CTN, Yogi LS, Pedrinelli A, Camargo OP. Validação da versão para a língua portuguesa do questionário de Medida Funcional para Amputados (Functional Measure for Amputees Questionnaire). Fisioter Pesq. 2008;15(2):164-71. 
12. Chamlian TR, Melo ACO. Avaliação funcional em pacientes amputados de membros inferiores. Acta Fisiatr. 2008;15(1):49-58.

13. Organização Mundial da Saúde. CIF: Classificação internacional de funcionalidade, incapacidade e saúde. São Paulo: Edusp; 2003.

14. Stucki G, Reinhardt JD, Grimby G, Melvin J. O desenvolvimento da "Pesquisa em funcionalidade humana e reabilitação" a partir de uma perspectiva abrangente. Acta Fisiatr. 2008;15(1):63-9.

15. Ciconelli RM, Ferraz MB, Santos W, Meinão I, Quaresma RM. Tradução para o português e validação do questionário genérico de avaliação de qualidade de vida SF-36. Rev Bras Reumatol. 1999;39(3):580-8.

16. Correia TS, Tamashiro LH, Chamlian TR, Masiero D. Avaliação da qualidade de vida e independência funcional em pacientes amputados de membro inferior. Med Reabil. 2006;26(1):7-10.

17. Larsson B, Johannesson A, Andersson IH, Atroshi I. The locomotor capabilities index: validity and reliability of the Swedish version in adults with lower limb amputation. Health Qual Life Outcomes. 2009;7:44.

18. Zidarov D, Swaine B, Gauthier-Gagnon C. Quality of life of persons with lower-limb amputation during rehabilitation and at 3-month follow-up. Arch Phys Med Rehabil. 2009;90:634-45.

19. van der Schans CP, Geertzen JH, Schoppen T, Dijkstra PU. Prosthetic history, prosthetic charges, and functional outcome of the isolated, traumatic below-knee amputee. J Pain Symptom Manage. 2002;24(4):429-36.

20. Smith DG, Horn P, Malchow D, Boone DA, Reiber, GE, Hausen ST Jr. Prosthetic history, prosthetic charges, and functional outcome of the isolated, traumatic below-knee amputee. J Trauma. 1995;38(1):44-7.

21. Røe C, Sveen U, Cieza A, Geyh S, Bautz-Holter R. Validation of the Brief ICF core set for low back pain from the Norwegian perspective. Eur J Phys Rehabil Med. 2009;45:403-14.

22. Long JS, Pavalko E. Comparing alternative measures of functional limitation. Med Care. 2004;42(1):19-27.

23. Dahl TH. International classification of functioning, disability and health: an introduction and discussion of its potential impact on rehabilitation services and research. J Rehabil Med. 2002;34(5):201-4.
24. Kohler F, Cieza A, Stucki G, Geertzen J, Burger H, Dillon MP, et al. Developing Core Sets for persons following amputation based on the International Classification of Functioning, Disability and Health as a way to specify functioning. Prosthet Orthot Int. 2009;33(2):117-29.

25. Farin E, Fleitz A, Frey C. Psychometric properties of an international classification of functioning, disability and health (ICF)-oriented, adaptive questionnaire for the assessment of mobility, self-care and domestic life. J Rehabil Med. 2007;39(7):537-46.

26. Pollard B, Dixon D, Dieppe P, Johnston M. Measuring the ICF components of impairment, activity limitation and participation restriction: an item analysis using classical test theory and item response theory. Health Qual Life Outcomes. 2009;7:41.

27. Lima MAG, Neves RF, Tironi MOS, Nascimento AMDN, Magalhães FB. Avaliação da funcionalidade dos trabalhadores com LER/DORT: a construção do Core Set da CIF para LER/DORT. Acta Fisiatr. 2008;15(4):229-35.

28. Monteiro RP, Pfeifer LI, Soares I, Santos AD, Sousa N. Validation of the functional and social performance DSF-84 checklist: preliminary study. Disabil Rehabil. 2013;35(18):1527-33. doi: 10.3109/09638288. 2012.745624 .

29. Burger H. Can the International Classification of Functioning, Disability and Health (ICF) be used in a prosthetics and orthotics outpatient clinic? Prosthet Orthot Int. 2011;35(3):302-9.

30. Kohler F, Xu J, Silva-Withmory C, Arockiam J. Feasibility of using a checklist based on the International Classification of Functioning, Disability and Health as an outcome measure in individuals following lower limb amputation. Prosthet Orthot Int. 2011;35(3):294-301.

Received: 05/13/2013

Recebido: 13/05/2013

Approved: 01/05/2014 Aprovado: 05/01/2014 